\title{
Analysis of the Influence of the Quality of Financial Accounting on the Enterprise
}

\author{
Yinhua Liao
}

Jiangxi University Of Engineering, Jiangxi, Xinyu, 338000

\section{key words Financial Accounting; work quality; Enterprise Competition}

\begin{abstract}
The growth and development of social and economic benefits have been accelerating, and the competition among enterprises in the market has intensified. In order to improve their competitive advantages and economic benefits in the market, enterprises have made a series of changes in financial accounting in order to improve their own control in various fields. Some enterprises not only predict the work quality of financial accounting, but also detect and evaluate the financial management. In these two aspects, enterprises can formulate the work management of financial accounting, formulate reliable management schemes and optimize the structure of the company according to the quality of accounting work. This paper discusses how to promote the importance of financial accounting in enterprises. the competitive advantage of enterprises in the market.
\end{abstract}

\section{Introduction}

It is an inevitable trend for enterprises not only to earn their interests to the maximum extent, but also to improve their competitive advantages in the market. Therefore, it is necessary for enterprise leaders to start enterprise management, especially on the quality of financial accounting. Through the economic benefit of the enterprise, we can roughly observe the benefit of the enterprise in the market, and the situation of the development of the enterprise can be clear at a glance. If the economic benefit of the company is not good, then the enterprise can find out its own problems and understand the causes to solve the fundamental problems. For example, the cost is too high, economic waste or the existence of misappropriation of public funds within the company and so on. At the same time, the enterprise When carrying out relevant economic activities, we must evaluate them with a scientific and rigorous attitude and technology. after the evaluation, we should plan the work of financial accounting in depth. Secondly, we should establish a communication network platform for financial accounting, which can not only be used for the communication between accountants, but also promote the efficiency of accounting, play a role in supervision, and ensure the accuracy and authenticity of finance. From the general situation to formulate a complete financial accounting management plan, improve accounting literacy, speed up the pace of enterprise development.

\section{2. one of the factors for the good development of enterprises: financial accounting}

Enterprises can take root in the market steadily and advance with reasonable acceleration can not be separated from finance, it plays an important role in the enterprise. And the core leaders of the enterprise can analyze the development of the enterprise through the income and expenditure of the economy, grasp the development direction of the enterprise, seize the opportunity of the enterprise in the market, improve the annual total income of the enterprise, and obtain higher economic benefit. According to the above discussion, there is no doubt that financial accounting is a heavyweight. It also accounts for a large proportion of the structure of the enterprise, aiming at the optimization of the structure of financial accounting, but also the optimization of the overall structure of the enterprise, so as to promote the enterprise in the fierce market competition. Advantage. 


\section{Elements of financial accounting for the development of enterprises.}

\section{1 cost control}

It is absolutely important to think of the stable long-term development of the enterprise and the control and adjustment of the cost. In the development of the enterprise, the cost is too high to hinder the progress of the company to a great extent, after all, the enterprise is in the interests of the base. Therefore, it is necessary to firmly control the cost of the development of the control company. At this time, it can be seen that the high-quality company's financial and accounting work has a good effect on the enterprise. The core competence of the enterprise can be enhanced, and the development of the company can be fundamentally promoted.

\subsection{Management of the area of finance}

The financial management of enterprises is the skill of competition between enterprises. Financial management is related to the level of balanced development of an enterprise and involves the flow of enterprise wealth, but the whole management malpractice of the enterprise can be obtained from the financial management. According to the authenticity of financial accounting data, the enterprise management level needs to make the real name of financial accounting, and make the reasonable working arrangement and division of labor clear, establish the enterprise rules and optimize the enterprise management.

\section{3 workload of accounting}

The workload of accounting mainly includes accounting measurement, which is to calculate income, expenditure, cost and so on by measuring units. The work of accounting should not be too complicated, according to a reasonable range, and the object of measurement should be rational and scientific. Under specific circumstances, efficiency and speed should be used to analyze the economic situation together. Remember that colleagues must negotiate a unified unit of measurement. Ensure the quality of financial statistics.

\section{4. the key role in the field of financial accounting in enterprises.}

\section{1 evidence for improving the economic efficiency of an enterprise}

According to their own economic benefits, enterprises can intuitively obtain the management status of enterprises. Enterprise leaders can examine the relevant economic activities of the enterprise year in detail, examine each economic link, and judge which economic activities of the enterprise are a kind of unproductive expenditure in the market, so as to reduce the economic activities and reduce the cost of this kind of item, and then formulate specific accounting measures according to the economic benefits, optimize the quality and efficiency of the work, and improve the operating level of the enterprise.

\subsection{Financial accounting plays a guiding role in enterprises}

Why does the financial accounting of enterprises have the function of index? Financial accounting is an assessment of the company's total income benefits, which will be detailed to the nature of each economic activity. Therefore, the top management of the enterprise can control the direction of capital flow, compare the economic benefits of previous years to make a reasonable investment plan and market competition, followed by the detailed work content and responsibilities for each part of the enterprise. Economic activities that occupy the resources of the company can be excluded and deleted. It is a good basis for making decisions and plans for the senior management of the company, so it plays a role in pointing out the direction for the enterprise.

\section{3 reasonable analysis of the current situation of enterprise management}

The company's accounting work can effectively reflect the company's real-time operating situation. And accurate control of every piece of the company's capital flow, such as the company's total capital, profit margins, capital use and so on. Through reasonable and scientific analysis of relevant 
accounting data, we can reflect the current situation of enterprises. So as to avoid the possible risks, and combined with the law of market development, timely adjustment of enterprise work development center, so as to conform to the trend of the times, sustainable development.

\section{To improve the level of financial accounting and to optimize the specific scheme of the quality of work}

\subsection{Accounting Analysis of efficiency}

Financial accountants must evaluate the efficiency according to the facts, and enterprises need to formulate an effective accounting supervision program in the face of financial departments. For example, after the financial accountant measures the income and expenditure of the company, the enterprise can master the details and dynamics of the accountant's work, and supervise the authenticity of the financial accounting from the outside. At the same time, the enterprise can not rely solely on the conscious responsibility of the financial accountant, the enterprise should design the system of honoring the financial accountant, let the financial accountant make favorable suggestions out of sincerity and consider the interests of the enterprise. Make the financial accountant carry on the effective evaluation and the report from each situation of the enterprise.

\section{2 improve the supervision programme of financial accounting}

Financial accounting is related to the whole interests of the company, and the authenticity of natural data is particularly important. The supervision scheme of financial accounting in many enterprises is full of holes, so it has lost its favorable advantage in the competition of the market. Therefore, it is an inevitable problem for enterprises to supervise the program, and it will also greatly improve the fluency of financial accountants.

\section{3 improve the comprehensive literacy of financial accountants}

Enterprises should also focus on the training of accounting talents. An excellent financial accountant brings inestimable benefits to the enterprise, not only the smooth time benefit in the work, but also the efficient work results. Professional and skilled financial accountants are the biggest optimizations because they have the ability to optimize the quality of their work. Their knowledge structure and pluralistic thinking can always provide useful advice or solutions. Therefore, enterprises should train and invite tenders for this kind of high-quality financial accountants, and make use of excellent resources to create wealth for the company. The company can make a talent training plan for existing financial accountants To get deeper technical training and knowledge edification, in thought, to educate financial accountants to actively treat the work, to improve their happiness index in the company is also to enhance the sense of responsibility of financial accounting to the company.

\subsection{Improvement of financial work}

In order to effectively improve the economic benefits of the company, we must perfect and optimize the financial work of the enterprise at all times. As far as the optimization work is concerned, the first is to perfect and optimize the financial and accounting management system, the management system should always follow the development of the times, combined with the actual situation of the enterprise to actively update and optimize. The second is to make clear the functions of the relevant personnel in the management process, improve the supervision and management ability of the enterprise, ensure the true effectiveness of the work, and make the financial work give full play to its due value.

\section{Conclusion:}

According to all the above-mentioned discussion, it can be said that the quality of work of financial accounting is the nuclear power of the company's development, and the enterprise needs to reform and promote the financial management of the company, and can't keep pace with self-sealing and 
make the frog of the well, especially in the background that the market is becoming more and more competitive, The enterprise should know that innovation is the way of survival, and the quality of financial accounting is the competitive advantage of the company.

\section{References:}

[1] Wang Bingyan. How that quality of the financial accounting work affect the economic benefit of the enterprise[J]. Modern Marketing (Business Edition),2019 (7).

[2] $\mathrm{Xu}$ Min. How that quality of the financial accounting work affect the economic benefit of the enterprise[J]. Modern Economic Information,2018 (9).

[3] Yang Jian. Based on the analysis of the influence of financial accounting background on the internal control of enterprises [J]. Modern Economic Information, 2015 (5).

[4] Shen Lei. On the far-reaching influence of financial accounting on the economic benefits of enterprises [J]. Private Science and Technology, 2011 (3).

[5] Wu Dongxia. Research on the Development of Financial Accounting based on the era of Network economy [J]. Modern Marketing (late issue), 2015 (04): 85

[6] Chu Fengrong, Dong Xiao. Research on Financial Accounting under the condition of Network economy [J]. Mall Modernization, 2015 (11): 96.

[7] Ding Youxuan. On Financial Accounting Management in the era of Network economy [J]. Modern Economic Information, 2015 (16): 95.

[8] Li Tingting. Research on the Development of Financial Accounting in the era of Network economy [J]. Economist, 2018 (10): 23. 